\title{
Predicting Academic Success From Academic Motivation And Learning Approaches In Classroom Teaching Students
}

Barış Çetin, Ph.D., Canakkale 18 Mart University, Turkey

\begin{abstract}
$^{1}$
Our aim was to determine whether learning approaches and academic motivation together predict academic success of classroom teaching students. The sample of the study included 536 students (386 female, 150 male) studying at the Classroom Teaching Division of Canakkale 18 Mart University. Our research was designed as a prediction study. Data was collected by using "The revised two-factor Study Process Questionnaire" developed by Biggs, Kember, and Leung (2001) and adapted to Turkish by Yilmaz (2009), "The Academic Motivation Scale" developed by Vallerand et al. (1992) and adapted to Turkish byEymur and Geban (2011), and "The Personal Information Form". It was found that there is not a relationship between academic success and learning approaches. There was no significant correlation between academic success and academic motivation. Academic motivation and learning approaches were correlated ( $r=.258)$. Academic motivation and learning approaches, together, explained academic success (.078).
\end{abstract}

Keywords: Classroom Teaching; Learning Approaches; Academic Motivation; General Academic Success

\section{INTRODUCTION}

\section{Academic Motivation}

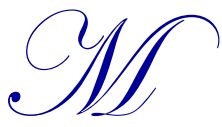

otivation theories are founded on assumptions about the human nature (Deci \& Ryan, 1985). The concept of motivation takes maintaining and guiding behaviors and innate strengths as reference (Petri, 1981; cited by Vallerand \& Losier, 1994). Deci and Ryan (1985) separated motivation into three categories: amotivation, extrinsic motivation and intrinsic motivation (Cited by Deci \& Ryan, 2002). Amotivation takes the lack of motivation and the observation of the individual's inability to sense the conditions between his or her actions and consequences as reference (Ratelle, Guay, Vallerand, Larose, \& Sene'cal, 2007). Amotivation occurs when a person cannot get positive feedback regarding his/her performance or believes that he/she fails on a repetitive basis. According to revised theory of helplessness, noncontingent environments lead to amotivation. Amotivation results when one perceives oneself as incompetent to reach intended outcomes (Deci \& Ryan, 1985).

A person engages in intrinsically motivated behaviors in order to feel competent and self-determining. There are two general types of intrinsically motivated behaviors. A stimulation free environment would lead one to feel incompetent and not self-determining and therefore to seek out ways for feeling competent and selfdetermining. The other type of intrinsically motivated behavior involves conquering challenges or reducing incongruity (Deci, 1975). Intrinsic motivation depends on the innate need for competence and self-determination. It provides the fuel for various behaviors and psychological processes. Intrinsic needs are different from primary drives because they are not based in tissue deficits and they do not function cyclically. However, both of them are

1This article was presented at 9th International Balkans Education and Science Congress 16-18 October 2014and this is the extended version of the article of which was published) 
innate and provide an energy source for behavior (Deci \& Ryan, 1985). Extrinsic motivation is separated into four categories such as external regulation, introjected regulation, identified motivation and integrated regulation (Deci \& Ryan, 2002).

External regulation occurs when students relate results in order to control for the function of time and rewards they attribute to learned activities (Zimmerman, 2012). The least autonomous type of extrinsic motivation is external regulation, which involves being motivated to obtain rewards or avoid punishments. External regulation has an external perceived locus of causality (Skinner, 1953; cite by Deci \& Ryan, 2002).

Introjected regulation refers to an internalized external regulation but which is not truly accepted as one's own. It is some form of partially internalized extrinsic motivation. Introjection-based behaviors are performed in order to avoid guilt or to produce ego enhancements and feelings of worthiness. This type of regulation depends on contingent self-esteem (Deci \& Ryan, 1995; Cite by Deci \& Ryan, 2002).

Regulation through identification is a more self-determined form of extrinsic motivation, since it includes valuing of a behavioral goal or regulation. Identification is important in transforming external regulation into true self-regulation. Identification is accompanied by high-perceived autonomy. Identifications seem to have an internal perceived locus of causality (Deci, \& Ryan, 2002). Identification is the process of specification of an activity by its value and this way an acceptable regulation of one's dynamism is taken as reference (Vansteenkiste, Lens, \& Deci, 2006).

Integrated regulation is the basis for the most autonomous form of extrinsically motivated behavior. Integrated regulation results when identifications have been assessed and brought into congruence with the personally endorsed values, goals, and needs that are part of the self. Previous studies showed that integrated extrinsically motivated behaviors are associated with more positive experiences than the less fully internalized forms of extrinsic motivation. Integration of external motivation is mostly internal and integration occurs when individuals relate to their own schematics and their own activities (Zimmerman, 2012).

Self-determination refers to choosing between alternatives and the experience of an international perceived locus of causality. Self-determination is an important part of intrinsically motivated behavior and also of some extrinsically motivated behaviors. Self-determination is also a need. It facilitates developing competencies and reaching a flexible accommodation with the social environment, which is central to the development of extrinsic motivation (Deci \& Ryan, 1985). Will and self-determination are associated because, in order to be self-determining, people have to decide how to act on their environment and they would not prefer a condition where all of their needs are instantly satisfied without them making choices (Pintrich \& Schunk, 2002).

Self-determination theory is a concept included in intrinsic motivation. Self -determination theory takes the experience of freedom inside one's commencing behavior as reference. Self-determination often includes results or one's environmental control and choices (Deci \& Ryan, 1985). Self-determination theory takes personal growth, self-arrangement, global psychological needs, purpose of living, longings, energy and validity, unaware periods, cultural relations for motivation, and effects of motivation on social environments as reference (Deci \& Ryan, 2008).

\section{Approaches To Learning}

Studies on student's learning started with Marton and Saljo's (1976) study, which investigated deep and surface approaches to learning (Marton \& Saljo, 1976). The main purpose of good education is to direct students to use a deep approach and to prevent the use of the surface approach (Biggs, 1999).

The "deep approach" which emphasizes understanding learning processes, is clearly different concept from organizing effort and concentration related studying strategies (Entwisle \& McCune, 2004). The majority of previous studies on student learning considered high quality learning in terms of the deep approach, which results in conceptual understanding (Entwisle, 2005). The deep approach is directed by the need to complete a task in an appropriate and meaningful way, which leads to using the most appropriate cognitive functions for working on a task. The use of the deep approach creates positive feelings such as interest, feeling important, challenge, and even exhilaration. The surface approach is not only seen in learning but also in many other areas such as teaching or 
doing business. The surface approach can be expressed by the common idioms "cutting corners" or "sweeping under the carpet" (Biggs, 1999).

A student who uses the deep approach would not have the intention of finding shortcuts for dealing with a task. Instead, he/she would try to find meaning in the taught material and learn in the most wanted way (Biggs, 2012). In the surface approach, students try to guess what their teachers would expect from them in examinations and search for expected questions within the taught material. Students who depend on the deep approach handle a task with the intention of learning the material for themselves, which in turn would enable them to comprehend the meaning of the taught material (Entwisle, 2009).

Students who use the surface approach fail to grasp the real purpose of a task and try to finish the task by investing the minimum amount time and effort in order to meet learning requirements. As a result, low level cognitive activities are used even if the task requires higher level activities. In this regard, rote learning content without understanding it is very common. However, rote learning itself does not necessarily mean that the surface approach is used and is an appropriate method when verbatim recall is required. The inappropriate use of rote learning indicates a surface approach, such as memorizing answers of a previous examination (Biggs, 2001). When the surface approach is adopted, the learners focus on the surface characteristics of a situation, on the wording of a text, of the proposed argument, on figures in a problem, and on the formulas for solving a problem (Bowden \& Marton, 1998).

As mentioned before, the deep approach depends on the intrinsic interest to complete the task in an appropriate and meaningful way. In this regard, the underlying meaning and the main ideas, themes, and principles become important instead of the details and unsupported specifics. A deep approach, which uses analogy, metaphors, and conceptual structures, requires a strong background on relevant prior knowledge. The main characteristic of the deep approach involves students engaging in a task by using the most appropriate learning processes for completing the task satisfactorily (Biggs, 2001).

While the surface approach requires routine memorization, the deep approach involves making connections with previous knowledge and reasoning. The essence of the surface approach is that it does not only include rote learning but the use of rote learning, which derives from the intention to reproduce the material presented by the teacher, in a routine way and without thinking. When students' perceptions on the teaching-learning environment were examined, it was found that the deep approach is affected by "good teaching" and "freedom in learning" (Entwisle \& Smith, 2002). Neither the surface nor the deep approaches to teaching are the personality characteristics of a teacher. Using the deep approach and avoiding the surface approach forms the basis of high quality teaching, however, many traditional methods have the opposite effect (Biggs, 1999). The most important distinction between two approaches is that surface approach focuses on "the sign", whereas a deep approach focuses on "the signified". Deep approach was associated with comprehending the author's message, while surface approach involves misunderstanding the message (Marton \& Booth, 2009).

\section{PURPOSE}

The purpose of this study is to determine if approaches to learning and academic motivation together predict GPA in students who study at Primary School Education in Turkey.

\section{METHODS}

The model of this study is a prediction study since the aim was to determine predictive relationships of academic motivation and approaches to learning together to GPA for the students studying at Primary School Education (McMillan, 2008; Lodico, Spaulding, \& Voegtle, 2010)

\section{Participants}

The sample of the study consisted of 536 students (150 male and 386 female) studying at Primary School Education Department at Canakkale Onsekiz Mart University during the 2012-2013 spring term. 


\section{Materials}

\section{Academic Motivation Scale}

In this study, the scale that was arranged by in Turkish Eymür and Geban (2011) and developed by Vallerand and others (1992) was used.

The scale includes 28 items and 7 factors, each factor includes 4 items, and each item has 7 response categories. The scale consists of 3 intrinsic motivation factors, 3 extrinsic motivation factors, and one factor of amotivation. These factors are intrinsic motivation - to know, intrinsic motivation - toward accomplishment, intrinsic motivation - to experience stimulation, extrinsic motivation - identified, extrinsic motivation - introjected, extrinsic motivation - external regulation and amotivation. Scores obtained from the sub factors range between 4 and 28 and there are no reverse scored each item in the scale (Vallerand et al., 1992; Eymür \& Geban, 2011). The reliability analysis results of Turkish scale, the reliability coefficients of the sub factors range from .60 to .84 and the Cronbach's alpha values of the sub factors change between .60 and .84 (Eymür \& Geban, 2011).

\section{The Study Process Questionnaire}

The Study Process Questionnaire which was developed by Biggs, Kember, \& Leung (2001) and adapted in Turkish by Y1lmaz (2009) was used in this study.

The revised two-factor questionnaire contains 20 items and was developed in order to enable teachers to evaluate the learning environment in their classrooms and. Each sub factors include 10 items and all items in the questionnaire are positive. The maximum score that can be obtained from the questionnaire is 100 , whereas the minimum score is 20 (Biggs, at all., 2001; Y1lmaz, 2009).

In order to examine validity of Turkish scale, exploratory and confirmatory factor analysis was done. The Turkish form of the scale was carried out to 400 university students for the validity and reliability after examining and confirming equivalency between English and Turkish versions. Cronbach's alpha was used to determine the reliability. The two sub factors of the questionnaire are the deep approach, which has a Cronbach's alpha coefficient of 0.79, and the surface approach, which has a Cronbach's alpha coefficient of 0.73 (Y1lmaz, 2009).

Grade point average (Turkey): It is the general average of the grades for all student courses during the first and seventh semester among students studying at Primary School Education Department at Canakkale 18 Mart University,

Personal information form: This form is designed with students' own declarations. The form consists of questions about GPA, gender, and year of study.

\section{Procedures}

Data were collected through "Academic Motivation Scale", "The Study Process Questionnaire" and "Personal Information Form" using face to face interviews from the students (150 male and 386 female) studying at Primary School Education, at Canakkale Onsekiz Mart University in the spring term of the 2012-2013 academic year.

Multiple regression is essentially used to predict and relationship between two or more predictor variables and a criterion variable (Fraenkel \& Wallen, 2006). Therefore, multiple regression was used in this study. Pearson correlation analysis was used for determining the relationship of GPA to scores obtained from the "Academic Motivation Scale" and the "The Study Process Questionnaire"; whereas multiple regression analysis was used for determining whether the "Academic Motivation Scale" and the "The Study Process Questionnaire" together predict GPA. 


\section{FINDINGS}

In this section, the results of the Pearson Product-Moment Correlation, which was carried out in order to determine whether there are significant correlations between primary school students' academic motivation and the study process questionnaireand GPSs, are provided. In addition, results of the multiple regression analysis, which was conducted for determining whether primary school students' academic motivation and academic self -regulation learning together predict GPAs, are given.

Table 1 shows the descriptive statics related to means and standard deviations obtained from the study process questionnaire.

Table 1. Means and standard deviations of approaches to learning

\begin{tabular}{lccc}
\hline & $\boldsymbol{N}$ & $\bar{x}$ & $\boldsymbol{S}$ \\
\hline Deep approaches & 536 & 2.9160 & .71201 \\
Surface approaches & 536 & 3.0000 & .71565 \\
Total scores of approaches to learning & 536 & 2.9347 & .51285 \\
\hline
\end{tabular}

Table 2 shows the descriptive statics related to means and standard deviations obtained from the academic motivation scale.

Table 2. Means and standard deviations of academic motivation

\begin{tabular}{lccc}
\hline & $\mathbf{N}$ & $\bar{x}$ & $S$ \\
\hline Knowledge of intrinsic motivation & 536 & 3.9832 & .69826 \\
Accomplishment of intrinsic motivation & 536 & 3.3918 & .87084 \\
Intrinsic motivation to experience stimulation & 536 & 3.6194 & .76410 \\
Identification of extrinsic motivation & 536 & 4.1082 & .71529 \\
Extrinsic motivation inducement & 536 & 3.2505 & .89345 \\
Regulation of extrinsic motivation & 536 & 4.1474 & .80112 \\
Amotivation & 536 & 2.2313 & 1.00588 \\
Academic motivation total scores & 536 & 3.4478 & .54779 \\
\hline
\end{tabular}

Table 3. Results of the multiple regression analysis regarding the prediction of GPAs by academic motivation and approaches to learning

\begin{tabular}{lccrrr}
\hline & $\mathbf{B}$ & Standard Error B & $\mathbf{B}$ & $\mathbf{t}$ & $\mathbf{p}$ \\
\hline Constant & 3.375 & .564 & .18 & 5.980 & .000 \\
Deep approach & .312 & .118 & .155 & 2.650 & .008 \\
Surface approach & -.263 & .126 & -.131 & -2.083 & .038 \\
Total scores of approaches to learning & -.083 & .195 & -.030 & -.425 & .671 \\
Knowledge of intrinsic motivation & .338 & .116 & .164 & 2.902 & .004 \\
Total scores of academic motivation & -.063 & .196 & -.024 & -.324 & .746 \\
Accomplishment of intrinsic motivation & -.284 & .100 & -.172 & -2.828 & .005 \\
Action of intrinsic motivation & -.033 & .100 & -.018 & -.334 & .739 \\
Identification of extrinsic motivation & .111 & .116 & .055 & .958 & .339 \\
Extrinsic motivation inducement & .157 & .088 & .097 & 1.782 & .075 \\
Regulation of extrinsic motivation & .076 & .097 & .043 & .786 & .432 \\
Amotivation & .038 & .073 & .027 & .518 & .605 \\
\hline
\end{tabular}

$\mathrm{R}=.279 \mathrm{R}^{2}=.078$

$\mathrm{F}_{(11-521)}=3.995, \mathrm{p}=.000$

According to Table 3, there was not significant difference between GPA and learning approaches and academic motivation $\left(\mathrm{R}=.279, \mathrm{R}^{2}=.078, \mathrm{p}<.001\right)$. As seen in Table 3 , academic motivation and learning approaches explain $0.78 \%$ of total variance analysis.

It was discovered from the results of Table 4 that there was a significant correlation between academic motivation and learning approaches. $(\mathrm{p}<.005)$. 
Table 4. Correlation results of GPA to academic motivation and approaches to learning

\begin{tabular}{|c|c|c|c|c|c|c|}
\hline & GPA & Deep approaches & Surface approaches & $\begin{array}{c}\text { Approaches to } \\
\text { learing total scores }\end{array}$ & $\begin{array}{c}\text { Knowledge of } \\
\text { intrinsic motivation }\end{array}$ & $\begin{array}{c}\text { Academic motivation } \\
\text { total score }\end{array}$ \\
\hline GPA & 1 & $.142^{* *}$ & $-.124^{* *}$ & -.012 & $.179^{* * *}$ & .080 \\
\hline Deep approach & $.142^{* * *}$ & 1 & .029 & $.528^{* * *}$ & $.384^{* *}$ & $327^{* *}$ \\
\hline Surface approach & $-.124^{* *}$ & .029 & 1 & $.591^{* *}$ & $-.090^{*}$ & $.143^{* *}$ \\
\hline Total scores of approaches to learning & -.012 & $.528^{* *}$ & $.591^{* *}$ & 1 & $.164^{* *}$ & $.257^{* *}$ \\
\hline Knowledge of intrinsic motivation & $.179^{* * *}$ & $.384^{* *}$ & $-.090^{*}$ & $.164^{* *}$ & 1.104 & $.499^{* *}$ \\
\hline Total scores of academic motivation & .080 & $.3047^{* *}$ & $.143^{* *}$ & $.257^{* * *}$ & $.499^{* *}$ & $1^{.499}$ \\
\hline Accomplishment of intrinsic motivation & .030 & $.421^{* *}$ & $\begin{array}{l}.145 \\
-.069\end{array}$ & $.229^{* *}$ & $.543^{* *}$ & $.588^{* *}$ \\
\hline Action of intrinsic motivation & .039 & $281^{* *}$ & $.103^{*}$ & $.232^{* *}$ & $.429^{* *}$ & $.520^{* *}$ \\
\hline Identification of extrinsic motivation & $.124^{* *}$ & $.212^{* *}$ & .029 & $.203^{* *}$ & $.404^{* *}$ & $.487^{* *}$ \\
\hline Extrinsic motivation inducement & $.096^{*}$ & $.166^{* * *}$ & $.085^{*}$ & $.159^{* * *}$ & $.344^{* *}$ & $.608^{* *}$ \\
\hline Regulation of extrinsic motivation & .076 & .048 & $.248^{* *}$ & $.119^{* *}$ & $.252^{* *}$ & $.450^{* *}$ \\
\hline Amotivation & -.067 & $\begin{array}{r}.040 \\
-.015\end{array}$ & $.265^{* *}$ & $.167^{* * *}$ & $-.197^{* *}$ & $.131^{* *}$ \\
\hline
\end{tabular}

\begin{tabular}{|c|c|c|c|c|c|c|}
\hline & $\begin{array}{l}\text { Accomplishment of } \\
\text { intrinsic motivation }\end{array}$ & $\begin{array}{c}\text { Action of intrinsic } \\
\text { motivation }\end{array}$ & $\begin{array}{c}\text { Identification of } \\
\text { extrinsic motivation }\end{array}$ & $\begin{array}{c}\text { Extrinsic motivation } \\
\text { inducement }\end{array}$ & $\begin{array}{c}\text { Regulation of } \\
\text { extrinsic motivation }\end{array}$ & Amotivation \\
\hline GPA & .030 & .039 & $.124^{* *}$ & $.096^{*}$ & .076 & -.067 \\
\hline Deep approach & $.421^{* *}$ & $.281^{* *}$ & $.212^{* *}$ & $.166^{* *}$ & .048 & -.015 \\
\hline Surface approach & -.069 & $.103^{*}$ & .029 & $.085^{*}$ & $.248^{* *}$ & $.265^{* * *}$ \\
\hline Total scores of approaches to learning & $.229^{* *}$ & $.232^{* *}$ & $.203^{* *}$ & $.159^{* *}$ & $.119^{* *}$ & $.167^{* *}$ \\
\hline Knowledge of intrinsic motivation & $.543^{* *}$ & $.429^{* * *}$ & $.404^{* *}$ & $.344^{* *}$ & $.252^{* * *}$ & $-.197^{* * *}$ \\
\hline Total scores of academic motivation & $.588^{* *}$ & $.520^{* *}$ & $.487^{* *}$ & $.608^{* *}$ & $.450^{* *}$ & $.131^{* *}$ \\
\hline Accomplishment of intrinsic motivation & 1 & $.441^{* *}$ & $.280^{* *}$ & $.477^{* *}$ & $.131^{* *}$ & .007 \\
\hline Action of intrinsic motivation & $.441^{* *}$ & 1 & $.332^{* *}$ & $.299^{* *}$ & $.159^{* *}$ & $-.107^{*}$ \\
\hline Identification of extrinsic motivation & $.280^{* *}$ & $.332^{* *}$ & 1 & $.333^{* *}$ & $.481^{* *}$ & $-.313^{* * *}$ \\
\hline Extrinsic motivation inducement & $.477^{* *}$ & $.299^{* *}$ & $.333^{* *}$ & 1 & $.330^{* *}$ & .048 \\
\hline Regulation of extrinsic motivation & $.131^{* *}$ & $.159^{* *}$ & $.481^{* *}$ & $.330^{* *}$ & 1 & $-.103^{*}$ \\
\hline Amotivation & .007 & $-.107^{*}$ & $-.313^{* *}$ & .048 & $-.103^{*}$ & 1 \\
\hline
\end{tabular}

Amotivation

.007

\section{CONCLUSION AND DISCUSSION}

This study revealed that there was a significant correlation between GPA and academic motivation and learning approaches. GPA was a significant correlation between deep approach and identification of extrinsic motivation, extrinsic motivation inducement, knowledge of intrinsic motivation. GPA was a significant negative corrrelation with surface approach. However, there was a relationshipbetween academic motivation and learning approaches with the level of $(\mathrm{r}=.257)$. According to this study, it was found that there was a significant positive correlation between students' GPA and deep approach, whereas there was a significant negative correlation between GPA and surfaceapproach. 
Contrary to our results, a significant relationship between motivation and academic achievement has been reported in the literature (Amrai, Motlagh, Zalani, \& Parhon, 2011; Özder \& Motorcan, 2013). Heikkilä and Lonka (2006) found a low positive correlation between academic average and the deep learning approach. Diseth (2002) found a negative correlation between the surface approach and the academic approach. Diseth (2007) determined a positive correlation between exam grades and the deep approach. Ekinci (2009) found a significant positive correlation between students' level of achievement and the deep and strategic learning approach scores and a significant negative correlation between surface learning approach scores and achievement. Lavender (2005) found a significant correlation between extrinsic motivation external regulation, which is one of the sub factors of academic motivation scale, and academic achievement. Cokley, Bernard, Cunningham, and Motoike (2001) found significant correlations between GPA and the amotivation, intrinsic motivation to know, intrinsic motivation to achieve, and intrinsic motivation to experience stimulation sub factors. Robinson (2003) detected a positive correlation between intrinsic motivation to achieve and achievement and a negative correlation between amotivation and achievement.

Our study findings indicate that academic motivation and learning approaches are not significantly correlated to students' GPAs. It is assumed that the similarity between students' GPAs is the reason for not finding a significant correlation between GPA and academic motivation and learning approaches. Another explanation for not finding a significant correlation between GPA and academic motivation and approaches to learning is that there is a largenumber of various factors that possibly affect GPA.

Academic motivation and learning approaches explain $0.78 \%$ of total variance analysis. A similar result was reported by other researchers. For instance, Komarraju, Karau, and Schmeck (2009) determined that amotivation and the intrinsic motivation to accomplish were the best predictors of achievement. Diseth (2003) found that approaches to learning predicted academic achievement. And according to Choy, O'Grady, and Rotgans (2012) it was found that students' approach to learning was a weak predictor of academic achievement. Burton and Sztaroszta (2007) found that the deep learning approach was not a positive predictor of academic achievement. Diseth, Pallesen, Brunborg, and Larsen (2010) have indicated that the approach to learning is an independent predictor of test performance. Salamonson et al. (2013) have found that surface and deep approaches to learning are important predictors of academic performance. Lizzio, Wilson, and Simons (2002) have determined that the surface approach to learning is a better predictor of GPAs than deep approaches to learning in college students. Komarraju, Karau, and Schmeck (2009) determined that the best predictors of achievement are amotivation and intrinsic motivation to accomplish.

We think that many factors affected the prediction of students' GPAs in our study. It was assumed that factors including intelligence, cognitive skills, attitudes, having willingly chosen the department a student studies at, thinking skills, studying habits, learning strategies, interest, attention, and self-efficacy possibly affect GPAs.

In addition, the similarity between students' GPAs may be the reason for not being able to predict students' GPAs from academic motivation and approaches to learning. It is thought that our study findings would be beneficial for researchers who study in the field of teacher training. In addition, our study results can be utilizedby managers and academicians who work at faculties of education and executives at the Ministry of Education in order to increase the quality of education provided for teacher candidates.

\section{AUTHOR INFORMATION}

Barış Çetin, Ph.D., Department of Elementary Education, Canakkale 18 Mart University Turkey. For information about the work described in this article correspondence should be addressed to: Barış Çetin, Ph.D. Canakkale 18 Mart University, Department of Elementary Education, Canakkale, Turkey, 17100. Email: bcetin@comu.edu.tr

\section{REFERENCES}

Amrai, K., Motlagh, S.E. , Zalani, H.A., \& Parhon, H. (2011).The relationship between academic motivation and academic achievement students. Procedia Social and Behavioral Sciences, 15, 399-402. Retrieved from http://www.sciencedirect.com/science/article/pii/S1877042811002904 
Biggs, J.B. (1999). Teaching for quality learning at university. Buckingham: Open University Press.

Biggs, J., Kember, D., \& Leung, D.Y.P. (2001). The revised two-factor Study Process Questionnaire: R-SPQ-2F. British Journal of Educational Psychology,71 (1), 133-149. Retrieved from http://www.johnbiggs.com.au/pdf/ex_2factor_spq.pdf

Biggs, J. (2001). Enhancing learning: A matter of style or approach?. In Sternberg R.J.\& Zhang, L.F. (Eds.), Perspectives on thinking, learning, and cognitive styles (pp.73-102). Lawrence Erlbaum Associates: Mahwah, NJ.

Biggs, J. (2012). Enhancing learning through constructive alignment. In Kirby, J.R. \& Lawson, M.J. (Eds.), Enhancing the quality of learning: Dispositions, instruction, and learning processes (pp.117-136). Cambridge University Press: Cambridge, New York, Melbourne, Madrid, Cape Town, Singapore, Sao Paulo, Delhi, Mexico City.

Bowden, J., \& Marton, F. (1998).The university of learning beyond quality and competence. Routledge Falmer Taylor \& Francis Group: London and New York.

Burton, L.B., \& Sztaroszta, J. (2007). The Relationship among Conceptions of Knowledge, Approaches to Learning, Personality, and Academic Success.Australian Psychological Society. Retrieved from 2007-09-29. http://eprints.usq.edu.au/3438/1/Burton_Sztaroszta.pdf

Choy, J.L.F., O'Grady, G. , \& Rotgans, J.I. (2012). Is the Study Process Questionnaire (SPQ) a good predictor of academic achievement? Examining the mediating role of achievement-related classroom behaviours. Instr Sci. 40, 159-172 Doi 10.1007/s11251-011-9171-8.

Cokley, K.O., Bernard, N., Cunningham, D., \& Motoike, J. (2001). A psychometric investigation of the academic motivation scale using a united states sample. Measurement and Evaluation in Counseling and Development, 34, 109-119. Retrieved from https://eds-b-ebscohost-

com.libez.lib.georgiasouthern.edu/eds/pdfviewer/pdfviewer?vid=3\&sid=764a094f-e0b0-4167-b3ea41b2c7c26409@sessionmgr115\&hid=115

Deci, E.L. (1975). Intrinsic motivation: Conceptualizations of intrinsic motivation. Plenum Press: New York and London.

Deci, E. L., \& Ryan, R. M. (1985). Intrinsic motivation and self-determination in human behavior. Plenum Press: New York and London.

Deci, E.L\& Ryan, R.M (2002). An Overview of Self -Determination Theory: Organismic-Dialectical Perspective. In E.L.Deci \&R.M.Ryan (Eds.), Handbook of self-Determination Research (pp.3-33). The University of Rochester Press: Rochester, NY.

Deci, E. L., \& Ryan, R.M (2008). Self-determination theory: A macrotheory of human motivation, development and health. Canadian Psychology, 49, 182-185. Retrieved from http://selfdeterminationtheory.org/faculty?id=86

Diseth, A. (2002). The Relationship between Intelligence, Approaches to Learning and Academic Achievement. Scandinavian Journal of Educational Research, Vol. 46, No. 2, 219-230. DOI: 10.1080/00313830220142218.

Diseth A. (2003). Personality and approaches to learning as predictors of academic achievement. European Journal of Personality Eur. J. Pers., 17, 143-155. DOI: 10.1002/per.469

Diseth, A. (2007). Students' evaluation of teaching, approaches to learning, and academic achievement. Scandinavian Journal of Educational Research, 51 ( 2), 185-204. DOI: 10.1080/00313830701191654

Diseth, A., Pallesen, S., \& Brunborg, G.S., Larsen, S.(2010). Academic achievement among first semester undergraduate psychology students: The role of course experience, effort, motives and learning strategies. High Educ. 59, 335352. DOI 10.1007/s10734-009-9251-8

Entwistle, N., \& McCune V. (2004). The Conceptual Bases of Study Strategy Inventories. Educational Psychology Review, 16, 4 ,325-345. Retrieved from https://eds-b-ebscohostcom.libez.lib.georgiasouthern.edu/eds/pdfviewer/pdfviewer?vid=3\&sid=34f10e71-c56b-4068-96bd7048f27bd36c@sessionmgr115\&hid=109

Entwistle, N. , \& Smith, C. (2002). Personal understanding and target understanding: Mapping influences on the outcomes of learning. British Journal of Educational Psychology, 72, 321-342. Retrieved fromhttps://eds-b-ebscohostcom.libez.lib.georgiasouthern.edu/eds/pdfviewer/pdfviewer?vid=3\&sid=c38f7484-bfb3-4ff7-b579fca2f85b439f@sessionmgr113\&hid=109

Entwistle, N. (2005). Learning outcomes and ways of thinking across contrastingdisciplines and settings in higher education. The Curriculum Journal.Vol. 16, No. 1, pp. 67 - 82. DOI: 10.1080/0958517042000336818

Entwistle, N. (2009). Universities into the $21^{\text {st }}$ century, teaching for understanding at University: Deep approaches and distinctive ways of thinking. Palgrave macmillan: New York.

Eymür, G.\& Geban, O. (2011). Kimya öğretmeni adaylarının motivasyon ve akademik basarilari. Eğitim ve Bilim. Vol.36, No: 161. Retrieved from http://egitimvebilim.ted.org.tr/index.php/EB/article/view/987/299

Ekinci, N. (2009). Learning Approaches of University Students. Education and Science. 2009, Vol. 34, No 151. Retrieved from http://egitimvebilim.ted.org.tr/index.php/EB/article/view/609/88

Fraenkel, J.R., Wallen, N.E. (2006). How to design and evaluate research in education. Mc Graw Hill Higher Education. 
New York, NY.

Heikkilä, A. ve Lonka, K. (2006). Studying in higher education: students' approaches to learning, self-regulation, and cognitive strategies. Studies in Higher Education, 31,1,99-117. Retrieved fromhttps://eds.b.ebscohost.com/eds/pdfviewer/pdfviewer?vid=3\&sid=4ea15f8e-b617-49d1-91ed12346a8644dc\%40sessionmgr111\&hid=101

Lavender, M.M.(2005). A comparison of academic motivation of academically prepared and academically unprepared community college students (Unpublished doctoral dissertation). The Florida State University College of Education, Florida, USA.

Lodico, M.G., Spaulding, D.T., Voegtle, K.H. (2010). Methods in educational research from theory to practice. JosseyBass A Wiley Imprint: San Francisco.

Lizzio, A. , Wilson, K., \& Simons, R. (2002). University students' perceptions of the learning environment and academic outcomes: Implications for theory and practice. Studies in Higher Education, 27, 27-52. DOI: $10.1080 / 03075070120099359$

Komarraju, M., Karau, S.J., \& Schmeck, R.R.(2009). Role of the big five personality traits in predicting college students' academic motivation and achievement. Learning and Individual Differences, 19, 47-52. Retrieved from http://psychology.okstate.edu/faculty/jgrice/psyc4333/FiveFactor_GPAPaper.pdf

Marton, F., \&Sa“ljo", R. (1976).On qualitative differences in learning.I—Outcome and process.British Journal of Educational Psychology, 46, 4-11. DOI: 10.1111/j.2044-8279.1976.tb02980.x

Marton, F. \& Booth, S. (2009). Learning and Awareness. Routledge Taylor\& Francis Group: New York and London.

McMillan, J. (2008). Educational Research Fundamentals for the consumer. Pearson Education: Boston.

Özder, H., \& Motorcan, A. (2013). An analysis of teacher candidates' academic: Motivation Levels with Respect to Several Variables. British Journal of Arts and Social Sciences, 15, 1, $42-53$ Retrieved from http://www.bjournal.co.uk/paper/BJASS_15_1/BJASS_15_01_04.pdf

Robinson, N.M. (2003). Academic motivation and its relationship to personality variables and achievement (Unpublished doctoral dissertation). Southern Illinois University: Carbondale.

Ratelle, C.F., Guay, F., Vallerand, R.J., Larose, S., Sene'cal, C. (2007). Autonomous, Controlled, and Amotivated Types of Academic Motivation: A Person-Oriented Analysis. Journal of Educational Psychology, Vol. 99, No. 4, 734746. Retrieved from http://www.er.uqam.ca/nobel/r26710/LRCS/papers/ratetal2007.pdf

Pintrich, P.R.; Schunk, D.H. (2002). Motivation in education theory, research, and applications. Upper Saddle River: New Jersey, Columbus, Ohio.

Salamonson, Y., Roslyn Weaver, R., Chang, S., Koch, J., Bhathal, R., Khoo, C., \& Wilson, I.(2013). Learning approaches as predictors of academic performance in first year health and science students. Nurse Education Today, 33, 729733.http://dx.doi.org/10.1016/j.nedt.2013.01.013

Vansteenkiste, M.; Lens, W., \& Deci, E.L.(2006). Intrinsic versus extrinsic goal contents in self-determination theory: Another look at the quality of academic motivation. Educational Psychologist, 41(1), 19-31. Retrieved from http://selfdeterminationtheory.org/SDT/documents/2006_VansteenkisteLensDeci_InstrinsicvExtrinsicGoal_EP.p $\underline{\mathrm{df}}$

Vallerand, R. J., Pelletier, L. G., Blais, M. R, Brière, N. M., Senécal, C., \& Vallières, E. F. (1992). The academic motivation scale: a measure of intrinsic, extrinsic, and amotivation in education. Educational and Psychological Measurement, 52, 1003-1017. Retrieved fromhttp://www.selfdeterminationtheory.org/SDT/documents/1992_VallerandPelletierBlaisBriere_EPM.pdf

Vallerand, R.J.; Losier, G.F.(1994). Self-determined motivation and sportsmanship orientations: An assessment of their temporal relationship. Journal of Sport \& Exercise Psychology, 16, 229-245. Retrieved from http://www.selfdeterminationtheory.org/SDT/documents/1994_VallerandLosier_JSEP.pdf

Yılmaz, B. M. (2009). Karma öğrenme ortamındaki üniversite öğrencilerinin öğrenme yaklaşımlarına göre ders başarılarına göre ders başarılarının, derse devamlarının, web materyalini kullanma davranışlarının ve ortama yönelik memnuniyetlerinin değerlendirilmesi (Yayınlanmammış Doktora Tezi).Yıldız Teknik Universitesi: İstanbul.

Zimmerman, B.J. (2012). Goal setting: A key proactive source of academic self-regulation. In Schunk, D.H. \& Zimmerman, B.J. (Eds.), Motivation and Self-Regulated Learning Theory, Research, and Applications (pp.267295). Routledge Taylor \&Francis Group: New York and London. 
NOTES 